\title{
Studies on the separation of some transition metals using trialkylimidazole as selective extractant
}

\author{
Elzbieta Radzyminska-Lenarcik ${ }^{1, *}$, and Katarzyna Witt $^{1}$ \\ ${ }^{1}$ Faculty of Chemical Technology and Engineering, UTP University of Sciences and Technology, Seminaryjna 3, PL-85326 Bydgoszcz, \\ Poland
}

\begin{abstract}
The possibility of $\mathrm{Cu}(\mathrm{II})$ ion separation from an equimolar $\mathrm{Cu}-\mathrm{Cd}-\mathrm{Zn}$ tertiary mixture by solvent extraction was investigated. The process was based on the use of 1,2,4-trimethylimidazole (TMI) and 1decyl-2,4-dimethylimidazole (DDMI) as extractant. Dichloromethane was used as the solvent in the extraction process. The dissociation constant of extractants were found potentiometrically. Extraction data were used for finding stability constants and partition constants for the complexes being formed in the aqueous solution. For TMI, separation coefficients for $\mathrm{Cu}(\mathrm{II})$ with regard to zinc and cadmium are 2.9 and 1.3 , respectively. For DDMI separation coefficients for $\mathrm{Cu}(\mathrm{II})$ with regard to zinc and cadmium are 1.4 and 1.6, respectively. Sparingly soluble in water 1-decyl-2,4-dimethylimidazole is a more useful extractant.
\end{abstract}

\section{Introduction}

Industrial wastewater containing heavy metals (eq. zinc, copper, cadmium) belongs to hazardous wastes. Wastewater discharge is a primary source of this metal release into the environment [1]. On the other hand, these metals are very important due to wide application in the manufacturing of alloys, batteries, pigments and metal plating [2]. Therefore, the recovery and recycling of heavy metals from various waste materials is necessary and very important to gain the metal values and protect the environment [2,3]. Moreover, the increasingly stringent regulations regarding the discharge of metals into the environment, and the increasing stress upon the recycling of effluents have focused the great interest on the development of new approaches for the recovery of metals from industrial wastes [4]. Cote scored copper, zinc and cadmium for strategic metals [5].

A survey of literature indicates that separation or removal of heavy metal ions from different aqueous solutions can be achieved by solvent extraction [6-9]. Several extractants have been proposed for separation of $\mathrm{Cu}(\mathrm{II}), \mathrm{Zn}(\mathrm{II})$, and $\mathrm{Cd}(\mathrm{II})$ from aqueous solutions, e.g., carboxylic acids [10], derivatives of phosphinic acid [11], derivatives of acid amides, trioctylamine [11], alkylphenylamines [12], complex oximes [13], crown ethers [14-16] derivatives of ketones [17-20], derivatives of pyridine $[21,22]$, as well as alkyl derivatives of imidazole [6, 23-25] and quaternary ammonium salt [26].

The possibility of using alkylimidazoles for solvent extraction of metals has been noted for a long time [2729]. They are now a fairly well-known group of basic ligands (extractants) whose properties can be easily modified. The $\mathrm{pK}_{\mathrm{a}}$ value of the imidazole molecule is 6.98 at $20^{\circ} \mathrm{C}$ [30]. The stability of its complexes with the cations of the $1^{\text {st }}$ row of transition metals is higher than ammonia due to the binding of $\pi_{\mathrm{M} \rightarrow \mathrm{L}}$ [31].<smiles>[R]c1nc([R])n([R7])c1[R]</smiles>

Fig. 1. General formula of alkylimidazole.

The alkyl group at position $1\left(\mathrm{R}_{1}\right.$ Fig. 1) slightly increases the basicity of the donor nitrogen atom as well as the stability of the complexes. Even small alkyl group at position $2\left(R_{2}\right.$ Fig. 1$)$ or $4\left(R_{3}\right.$ Fig. 1$)$ constitute a steric hindrance making it difficult to form of complexes with a rigid, hardly deformable coordination sphere with octahedral or flat symmetry. Although 2 or 4 substituted alkylimidazoles are stronger bases than 1-alkylimidazole their complexes have lower values of stability constants. The introduction of alkyl groups into the imidazole ring, irrespective of their location, reduces the water solubility in all homologous series of alkylimidazoles. Compounds containing a total of more than 5 carbon atoms in substituents are practically insoluble in water. They can be used for metal separation as extractants in hydrometallurgy or as a carrier in membrane techniques. So far, the extraction properties of 1 -alkylimidazoles [6, 32, 33], 1-alkyl-2-methylimidazoles [7, 34, 35], 1-alkyl2-ethylimidazoles [36], 1,2-dialkylimidazoles [23, 25] and 1-alkyl-4-methylimidazoles [25, 37] have been studied. On the other hand, our knowledge of donor and extraction properties of tri-substituted alkylimidazoles is very small.

The purpose of the present study was to determine the basicity, complexity and extraction properties of

\footnotetext{
* Corresponding author: elaradz@utp.edu.pl
} 
1,2,4-trimethylimidazole (TMI) and 1-decyl-2,3dimethylimidazole (DDMI) and to compare their effectiveness in copper(II) ion separation from an equimolar $\mathrm{Cu}-\mathrm{Cd}-\mathrm{Zn}$ mixture. TMI and DDMI molecules differ in their hydrophobicity. Methylene chloride was used as the dilutent in the solvent extraction process.

\section{Experimental}

\subsection{Reagents}

Inorganic chemicals: copper(II), zinc(II), cadmium(II), and potassium nitrates were of analytical grade and were supplied by POCh (Gliwice, Poland). Nitric acid was of analytical grade and were supplied by MERCK. Aqueous solutions were prepared with double distilled water (conductivity of $5 \mu \mathrm{S} / \mathrm{m}$ ).<smiles>Cc1cn(C)c(C)n1</smiles>

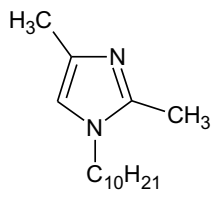

Fig. 2. Structure of the extrahents: 1,2,4-trimethylimidazole (TMI) and 1-decyl-2,4-dimethylimidazole (DDMI).

1,2,4-Trimethylimidazole (TMI) and 1-decyl-2,4dimethylimidazole (DDMI) (Fig. 2) were synthesized at Medical University of Lodz, Poland.

\subsection{Determination of dissociation constants $\left(\mathrm{pK}_{\mathrm{a}}\right)$}

The dissociation constants of TMI was determined by potentiometric titration. Measurements of $\mathrm{pH}$ were made using PHM 250 pH-meter (Radiometer) equipped with a glass-calomel combination electrode C 2401-8 (Radiometr). Measuring cell was thermostated at $25^{\circ} \mathrm{C} \pm$ $0.5^{\circ} \mathrm{C}$. Two solution were prepared. One contained nitric acid $\left(0.01 \mathrm{~mol} / \mathrm{dm}^{3}\right)$, ligand (TMI or DDMI), and a proper quantity of potassium nitrate to ensure a constant ionic strength $\left(0.5 \mathrm{~mol} / \mathrm{dm}^{3}\right)$. Another solution was prepared in a similar manner but without ligand. Measurements were taken for two ligand (TMI or DDMI) concentrations (0.06 $\mathrm{mol} / \mathrm{dm}^{3}$ and $0.05 \mathrm{~mol} / \mathrm{dm}^{3}$ ) in the first solution. A $20 \mathrm{~cm}^{3}$ volume of first solution was placed in the measuring cell, and the solution was titrated with the second. Three series of measurements were run.

\subsection{Solvent extraction}

Equal volumes of organic and aqueous phases (phase volume ratio $\mathrm{O} / \mathrm{A}=1$ ) were mechanically shaken for 20 $\min$ at $25 \pm 2{ }^{\circ} \mathrm{C}$. $0.05-0.25 \mathrm{~mol} / \mathrm{dm}^{3}$ ligand (TMI or DDMI) in dichloromethane was used as the organic phase. After establishing equilibrium, the aqueous phase was separated from the organic phase. Equilibrium $\mathrm{pH}$ of aqueous phases was measured with a Radiometr PHM 250 $\mathrm{pH}$-meter equipped with a glass-calomel combination electrode C 2401-8 (Radiometr). Metal ions concentrations in aqueous phases were analyzed with BUCK Scientific 210 VGP spectrophotometer (AAS Atomic Absorption Spectrometry). The concentrations of metal ions in aqueous phases were determined before and after solvent extraction for calculating extraction efficiency. The concentrations of metals in organic phases were deduced by mass balance. Each experiment was carried out three times and the error did not exceed $3 \%$.

\section{Results and discussion}

\subsection{Dissociation constant of ligands (TMI and DDMI)}

The acid dissociation constants of the protonated TMI and DDMI molecules were calculated from the equation:

$$
K_{a}=\frac{\left[\mathrm{H}_{3} \mathrm{O}^{+}\right][\mathrm{L}]}{\left[\mathrm{HL}^{+}\right]}=\frac{\left[\mathrm{H}_{3} \mathrm{O}^{+}\right]\left(\mathrm{C}_{\mathrm{L}}-\mathrm{C}_{\mathrm{HNO}_{3}}+\left[\mathrm{H}_{3} \mathrm{O}^{+}\right]\right)}{\mathrm{C}_{\mathrm{HNO}_{3}}-\left[\mathrm{H}_{3} \mathrm{O}^{+}\right]}
$$

where $\left[\mathrm{H}_{3} \mathrm{O}^{+}\right], \quad[\mathrm{L}]$, and $\left[\mathrm{HL}^{+}\right]$are equilibrium concentrations of the hydronium ion, the free ligand (TMI or DDMI) and its protonated form, respectively, where $\mathrm{C}_{\mathrm{L}}$ and $\mathrm{C}_{\mathrm{HNO}}$, are analitycal concentrations of the ligand and $\mathrm{HNO}_{3}$ in aqueous solution, respectively.

Table 1 presented the dissociation constants of the protonated TMI and DDMI together with the previously determined the dissociation constants of imidazole derivatives.

Table 1. Comparison of the dissociation constants $\mathrm{pK}_{\mathrm{a}}$ of chosen alkylimidazole derivatives in aqueous solution $\left(\mathrm{I}=0.5 \mathrm{~mol} / \mathrm{dm}^{3} \mathrm{~K}(\mathrm{H}) \mathrm{NO}_{3}\right)$ at $25^{\circ} \mathrm{C}$.

\begin{tabular}{|l|l|l|}
\cline { 2 - 3 } \multicolumn{1}{l|}{} & $\mathbf{p K _ { \mathbf { a } }}$ & ref. \\
\hline 1,2,4-trimethylimidzole (TMI) & 8.49 & [this work] \\
\hline 1-decyl-2,4-dimethylimidazole (DDMI) & 8.62 & [this work] \\
\hline imidazole & 6.99 & {$[30]$} \\
\hline 1-methylimidazole & 7.06 & {$[31]$} \\
\hline 2-methylimidazole & 8.10 & {$[38]$} \\
\hline 4-methylimidzole & 7.80 & {$[39]$} \\
\hline 1,2-dimethylimidzole (1,2-DMI) & 8.21 & {$[31]$} \\
\hline 1,4-dimethylimidzole (1,4-DMI) & 7.72 & {$[40]$} \\
\hline 2,4-dimethylimidazole (2,4-DMI) & 8.57 & {$[38]$} \\
\hline 4,5-dimethylimidzole (4,5-DMI) & 8.19 & {$[41]$} \\
\hline
\end{tabular}

The introduction of even a small alkyl group in positions 2 or 4 of the imidazole ring results in the molecule having a much higher basicity (Table 1). 2-Alkylimidazole and 4-alkylimidazole are harder bases in comparison with imidazole and 1-alkylimidazoles. 1,2,4Trimethylimidazole (TMI) is a stronger base than the 1,2dimethylimidazole (1,2-DMI), but 1-decyl-2,4dimethylimidazole (DDMI) is the strongest base. 


\subsection{Solvent extraction}

In the case where there is no phase change in volume, distribution ratio $\left(D_{M}\right)$ was defined as follows:

$$
D_{M}=\frac{C_{M(o r g)}}{C_{M(a q)}}=\frac{C_{M}^{0}-C_{M}}{C_{M}}
$$

where: $C_{M}^{0}$ and $C_{M}$ denote analytical metal concentrations in the aqueous phase before and after attaining a partition equilibrium, respectively.

Based on analytical calculations for every equilibrium $\mathrm{pH}$ value for the aqueous phase, the distribution ratios $\left(D_{M}\right)$ were calculated from formula (2) for each tested metal and then extraction curves were plotted $\left(\log \mathrm{D}_{\mathrm{M}}=\mathrm{f}(\mathrm{pH})\right)$ (Figs. 3 and 4).

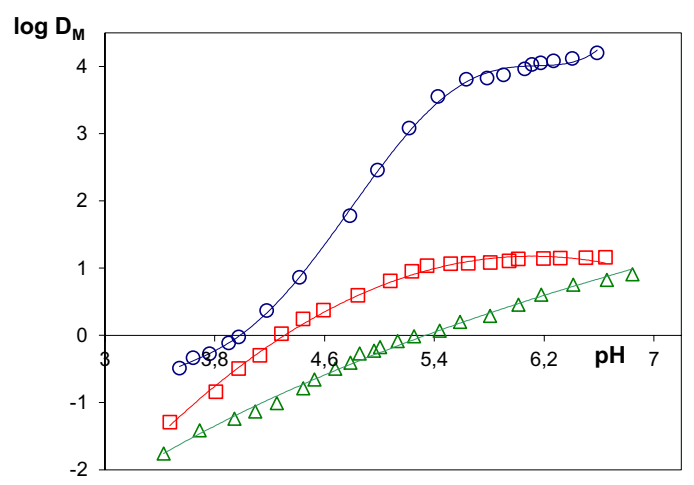

Fig. 3. Extraction curves of $\mathrm{Cu}(\mathrm{II})(O), \mathrm{Cd}(\mathrm{II})(\square)$, and $\mathrm{Zn}(\mathrm{II})$ $(\triangle)$ complexes with 1,2,4-trimethylimidazole (TMI) into dichloromethane.

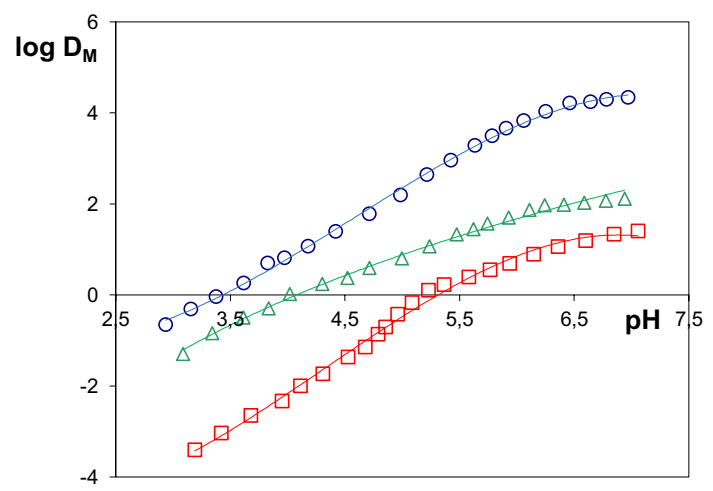

Fig. 4. Extraction curves of $\mathrm{Cu}(\mathrm{II})(\bigcirc), \mathrm{Cd}(\mathrm{II})(\square)$, and $\mathrm{Zn}$ (II) $(\triangle)$ complexes with 1-decyl-2,4-dimethylimidazole (DDMI) into dichloromethane.

Fig. 3 and Fig 4 indicate that partition ratios for the test metal complexes with TMI and DDMI tend to increase with an increase in the $\mathrm{pH}$ values of the aqueous phase.

For TMI (Fig.3), the order of extracted ions is $\mathrm{Cu}(\mathrm{II})>$ $\mathrm{Cd}(\mathrm{II})>\mathrm{Zn}$ (II), but for DDMI (Fig.4) $\mathrm{Cu}(\mathrm{II})>\mathrm{Zn}$ (II) $>$ $\mathrm{Cd}(\mathrm{II})$.

In the case of $\mathrm{Cu}(\mathrm{II})$ and $\mathrm{Cd}(\mathrm{II})$ complexes with TMI (Fig.3) for $\mathrm{pH}>5.8$ (for $\mathrm{Cu}(\mathrm{II})$ ) and 5.4 (for $\mathrm{Cd}(\mathrm{II})$ ) the values of $\mathrm{D}_{\mathrm{M}}$ are constant and they do not depend on the increase in the extractant's concentration in the aqueous and organic phases. Best extracted were $\mathrm{Cu}$ (II) complexes with TMI, worst extracted were $\mathrm{Zn}(\mathrm{II})$.

In the case of DDMI, the extraction of $\mathrm{Zn}(\mathrm{II})$ and $\mathrm{Cu}$ (II) complexes is almost the same at lower $\mathrm{pH}$ values (to about $\mathrm{pH}=5$ ), while for $\mathrm{Cd}(\mathrm{II})$ is much worse. Above $\mathrm{pH}=5.5$, the values of $\mathrm{D}_{\mathrm{M}}$ increase rapidly for $\mathrm{Cu}$ (II), but in case of $\mathrm{Cd}(\mathrm{II})$ and $\mathrm{Zn}(\mathrm{II})$ these values are approaching each other.

For TMI the values of $\mathrm{pH}_{1 / 2}$, corresponding to $50 \%$ of the extraction of copper, cadmium and zinc, are equal to 4.0, 4.3 and 5.3, respectively. This means, they can be separated by partition in the liquid-liquid system, conducting a multistep extraction at a $\mathrm{pH}$ value which is optimum for a given metal (Fig. 3).

For DDMI (Fig. 4), 50\% of the extraction of copper, cadmium and zinc, occurs at $\mathrm{pH}$ equal to $3.45,5.4$ and 4.05 , respectively.

Distribution ratio $\left(D_{M}\right)$ is related to stability constants of the complexes and their partition ratios by the following equation:

$$
D_{M}=\frac{P_{n} \beta_{n}[L]^{n}+P_{n+1} \beta_{n+1}[L]^{n+1}+\ldots . .+P_{N} \beta_{N}[L]^{N}}{\sum_{n=0}^{n=N} \beta_{n}[L]^{n}}
$$

where: $\beta_{n}$ are cumulative stability constants of the complexes in the aqueous phase, $P_{n}$ are organic solvent/water partition ratios of the complexes, $\left(\mathrm{P}_{\mathrm{n}}=\left[\mathrm{ML}_{\mathrm{n}}\right]_{(\mathrm{org})} /\left[\mathrm{ML}_{\mathrm{n}}\right]_{(\mathrm{aq})}\right),[\mathrm{L}]$ is the free ligand (TMI or DDMI) concentration $\left(\mathrm{mol} / \mathrm{dm}^{3}\right)$ in the aqueous phase and $\mathrm{n}$ is the number of ligands molecules in the first metal(II) complex that is so hydrophobic that it freely passes into the organic phase.

Cumulative stability constants are described by the equations:

$\beta_{1}=\frac{[M L]}{[M][L]} \quad \beta_{2}=\frac{\left[M L_{2}\right]}{[M][L]^{2}} \quad \ldots \quad \beta_{n}=\frac{\left[M L_{n}\right]}{[M][L]^{n}}$

The pooled $D_{\mathrm{M}}$ values and the corresponding sets of the independent variable $[L]$ were used for determination of the stability constants $\beta_{n}$ and partition ratios $\mathrm{P}_{\mathrm{n}}$ of the metal(II) complexes by using the equation proposed by Rydberg [42]:

$$
\frac{[L]^{n}}{D_{M}}=\frac{\sum_{n=0}^{n=N} \beta_{n}[L]^{n}}{P_{n} \beta_{n}}
$$

Equation (5) can be used for determination of the composition of the first complex being extracted from the aqueous phase and the stability constant, $\beta_{1}$, of the first complex formed in the aqueous phase. To do this, the shape of the function $[L]^{n} / D_{M}=f[L]$ is monitored when varying the exponent $n$ between 1 and 6 . In this way, a bundle of curves were obtained of which only one was a straight line with a positive slope and $b$ values. It is assumed that the $n$ value is equal to the number of ligand molecules attached to the central ion in the first complex 
being extracted. The method was used previously $[6,7$, $23-25,32-37]$. The stability constants, $\beta_{\mathrm{n}}$, obtained in this way are collected in Table 2 together with stability constants for 1,2-dimethylimidazole [31], and 1,4dimethylimidazole [40].

Table 2. Comparison of the stability constants $\beta_{n}$ of $\mathrm{Cu}(\mathrm{II})$, $\mathrm{Zn}(\mathrm{II})$, and Cd(II) complexes with 1,2,4-trimethylimidazole (TMI), 1-decyl-2,4-dimethylimidazole (DDMI), 1,2-dimethylimidazole (1,2-DMI), and 1,4-dimethylimidazole (1,4-DMI) at $25^{\circ} \mathrm{C}$, ionic strength $0.5 \mathrm{~mol} / \mathrm{dm}^{3}\left(\mathrm{KNO}_{3}\right)$.

\begin{tabular}{|c|c|c|c|c|c|c|}
\hline ligand/pK & $\begin{array}{c}\text { metal } \\
\text { ion }\end{array}$ & $\begin{array}{c}\log \\
\beta_{1}\end{array}$ & $\begin{array}{c}\log \\
\beta_{2}\end{array}$ & $\begin{array}{c}\log \\
\beta_{3}\end{array}$ & $\log \beta_{4}$ & ref. \\
\hline \multirow{3}{*}{$\begin{array}{l}\text { TMI } \\
8.49\end{array}$} & $\mathrm{Zn}(\mathrm{II})$ & 2.03 & 4.17 & 6.27 & 9.51 & \multirow{3}{*}{$\begin{array}{l}\text { [this } \\
\text { work] }\end{array}$} \\
\hline & $\mathrm{Cu}(\mathrm{II})$ & 3.75 & 6.83 & 9.26 & 11.38 & \\
\hline & $\mathrm{Cd}(\mathrm{II})$ & 2.34 & 3.79 & 5.32 & 6.95 & \\
\hline \multirow{3}{*}{$\begin{array}{l}1,2-\mathrm{DMI} \\
8.21\end{array}$} & $\mathrm{Zn}(\mathrm{II})$ & 1.92 & 4.32 & 7.11 & 9.00 & \multirow{3}{*}{ [31] } \\
\hline & $\mathrm{Cu}(\mathrm{II})$ & 3.70 & 6.80 & 9.18 & 10.80 & \\
\hline & $\mathrm{Cd}(\mathrm{II})$ & 2.20 & 3.45 & 5.05 & 6.34 & \\
\hline \multirow{3}{*}{$\begin{array}{l}\text { 1,4-DMI } \\
7.72\end{array}$} & $\mathrm{Zn}(\mathrm{II})$ & 1.70 & 4.48 & 5.40 & 8.90 & \multirow{3}{*}{ [40] } \\
\hline & $\mathrm{Cu}(\mathrm{II})$ & 3.54 & 6.53 & 9.17 & 10.47 & \\
\hline & $\mathrm{Cd}(\mathrm{II})$ & 2.05 & 3.93 & 5.11 & 5.81 & \\
\hline \multirow{3}{*}{$\begin{array}{l}\text { DDMI } \\
8.62\end{array}$} & $\mathrm{Zn}(\mathrm{II})$ & 2.17 & 4.48 & 6.39 & 9.87 & \multirow{3}{*}{$\begin{array}{l}\text { [this } \\
\text { work] }\end{array}$} \\
\hline & $\mathrm{Cu}(\mathrm{II})$ & 3.95 & 7.18 & 9.42 & 11.69 & \\
\hline & $\mathrm{Cd}(\mathrm{II})$ & 2.53 & 4.21 & 5.68 & 7.56 & \\
\hline
\end{tabular}

A comparison of the values of stability constants in Table 2 indicates that stability for all complexes tends to increase with ligand's alkalinity and is the highest for $\mathrm{Cu}$ (II) complexes. In the case of TMI, stability constants for $\mathrm{Zn}$ (II) complexes are higher than those for $\mathrm{Cd}(\mathrm{II})$ complexes.

In aqueous solutions, cations of $\mathrm{Zn}(\mathrm{II}), \mathrm{Cd}(\mathrm{II})$ and $\mathrm{Cu}(\mathrm{II})$ exist in the form of octahedral aquacomplexes $\left[\mathrm{M}\left(\mathrm{H}_{2} \mathrm{O}\right)_{6}\right]^{2+}$. Owing to the effect of ligands (extractants), octahedral aquacomplexes of certain cations tend to change their coordination number (c.n.) from 6 to 4 and they change their coordination sphere into flat or tetrahedral, depending on the structure of their d-electron layer. The process is illustrated by the equation.

$\left[\mathrm{M}\left(\mathrm{H}_{2} \mathrm{O}\right)_{6-\mathrm{n}+1} \mathrm{~L}_{\mathrm{n}-1}\right]^{2+}+\mathrm{L} \leftrightarrow\left[\mathrm{M}\left(\mathrm{H}_{2} \mathrm{O}\right)_{4-\mathrm{n}} \mathrm{L}_{\mathrm{n}}\right]^{2+}+(\mathrm{n}+2) \mathrm{H}_{2} \mathrm{O}$

Therefore, tetrahedral complex (c.n. $=4)$ are formed in the solution in addition to octahedral ones $(c . n .=6)$. Tetrahedral complexes are specific to $\mathrm{Zn}(\mathrm{II})$, and $\mathrm{Cd}(\mathrm{II})$. Also $\mathrm{Cu}(\mathrm{II})$ ions tend to change the symmetry of their coordination sphere, forming distorted tetrahedral or flat structures [43].

Changes in the coordination sphere lead to higher sums of complex stability constants (stability constants are the sum of the stability constants for the complexes with c.n. $=4$ and with c.n. $=6$ ) and higher susceptibility to extraction in the liquid-liquid system, because complexes with the c.n. $=4$, being less hydrated, pass more readily into the organic phase after at least part of the molecules of water, which is bound in the metal coordination sphere, is replaced by the molecules of the more hydrophobic ligand. For the fourth stage of complexation $(n=4)$ this can be illustrated by the following equations:

$$
\begin{gathered}
{\left[\mathrm{M}\left(\mathrm{H}_{2} \mathrm{O}\right)_{6}\right]^{2+}+4 \mathrm{~L} \leftrightarrow\left[\mathrm{ML}_{4}\right]^{2+}+6 \mathrm{H}_{2} \mathrm{O}} \\
{\left[\mathrm{M}\left(\mathrm{H}_{2} \mathrm{O}\right)_{6}\right]^{2+}+4 \mathrm{~L} \leftrightarrow\left[\mathrm{ML}_{4}\left(\mathrm{H}_{2} \mathrm{O}\right)_{2}\right]^{2+}+2 \mathrm{H}_{2} \mathrm{O}}
\end{gathered}
$$

wherein L is the extractant (TMI or DDMI) molecules.

Table 3. Comparison of the partition ratios $P_{n}$ of Cu(II), Zn(II), and Cd(II) complexes with 1,2,4-trimethylimidazole (TMI), 1-decyl-2,4-dimethylimidazole (DDMI) and 1,4-dimethylimidazole (1,4-DMI) between the aqueous and the organic

\begin{tabular}{|c|c|c|c|c|c|c|}
\hline $\begin{array}{l}\text { ligand/ } \\
\text { solvent }\end{array}$ & $\begin{array}{c}\text { metal } \\
\text { ion }\end{array}$ & $\mathbf{P}_{1}$ & $\mathbf{P}_{2}$ & $\mathbf{P}_{3}$ & $\mathbf{P}_{4}$ & ref. \\
\hline \multirow{3}{*}{$\begin{array}{c}\text { TMI } \\
\text { methylene } \\
\text { chloride }\end{array}$} & $\mathrm{Zn}(\mathrm{II})$ & & 0.84 & 1.23 & 29.21 & \multirow{3}{*}{$\begin{array}{l}\text { [this } \\
\text { work] }\end{array}$} \\
\hline & $\mathrm{Cu}(\mathrm{II})$ & & 1.26 & 1.87 & 84.72 & \\
\hline & $\mathrm{Cd}(\mathrm{II})$ & & 0.3 & 1.56 & 65.46 & \\
\hline \multirow{3}{*}{$\begin{array}{c}\text { 1,4-DMI } \\
\text { benzyl } \\
\text { alcohol }\end{array}$} & $\mathrm{Zn}(\mathrm{II})$ & & & & 8.72 & \multirow{3}{*}[40]{} \\
\hline & $\mathrm{Cu}(\mathrm{II})$ & & 0.1 & 1.65 & 20.75 & \\
\hline & $\mathrm{Cd}(\mathrm{II})$ & & & 1.54 & 110.7 & \\
\hline \multirow{3}{*}{$\begin{array}{c}\text { DDMI } \\
\text { methylene } \\
\text { chloride }\end{array}$} & $\mathrm{Zn}(\mathrm{II})$ & & 1.12 & 2.46 & 76.43 & \multirow{3}{*}{$\begin{array}{l}\text { [this } \\
\text { work] }\end{array}$} \\
\hline & $\mathrm{Cu}(\mathrm{II})$ & & 0.98 & 2.15 & 106.8 & \\
\hline & $\mathrm{Cd}(\mathrm{II})$ & & 0.15 & 1.71 & 67.39 & \\
\hline
\end{tabular}
phases, at $25^{\circ} \mathrm{C}$, ionic strength $0.5 \mathrm{~mol} / \mathrm{dm}^{3}\left(\mathrm{KNO}_{3}\right)$.

The partition ratios between the aqueous and organic phases for the investigated metal complexes with TMI and DDMI, were found from Equation (5), and they are collected in the Table 3 together with partition ratios for the $\mathrm{Cu}(\mathrm{II}), \mathrm{Zn}(\mathrm{II})$ and $\mathrm{Cd}(\mathrm{II})$ complexes with 1,4dimethylimidazole (1,4-DMI) [40].

The data in Table 3 indicate that in the process of extraction of the tested metal complexes with TMI and DDMI as well as 1,4-DMI [40], mainly the fourth complexes tend to pass into the organic phase. The partition constants $\mathrm{P}_{4}$ (Table 3) well reflect susceptibility to extraction of the tested metal complexes with TMI and DDMI. Their high values are proof that, most probably, they are 4-coordination complexes of the formula $\left[\mathrm{ML}_{4}\right]\left(\mathrm{NO}_{3}\right)_{2}$. Extraction order for depends on extractant, for TMI extraction order was $\mathrm{Cu}(\mathrm{II})>\mathrm{Cd}(\mathrm{II})>\mathrm{Zn}(\mathrm{II})$, but for DDMI $-\mathrm{Cu}(\mathrm{II})>\mathrm{Zn}(\mathrm{II})>\mathrm{Cd}(\mathrm{II})$.

For TMI separation coefficients $\mathrm{Cu}(\mathrm{II})$ with regard to $\mathrm{Zn}(\mathrm{II})$ and $\mathrm{Cd}(\mathrm{II})$, calculated as $\mathrm{S}=\mathrm{P}_{4(\mathrm{Cu})} / \mathrm{P}_{4(\mathrm{M})}$, are 2.9 and 1.3, respectively. For DDMI separation coefficients $\mathrm{SCu}(\mathrm{II}) / \mathrm{Zn}(\mathrm{II})$ decreased (1.39), but $\mathrm{S}_{\mathrm{Cu}(\mathrm{II}) / \mathrm{Cd}(\mathrm{II})}$ increased (1.58).

\section{Conclusion}

The results of the presented investigation prove that 1,2,4trimethylimidazole and 1-decyl-2,4-dimethyl-imidazole in dichloromethane can be successfully used as the selective extractant for copper(II) from the $\mathrm{Cu}-\mathrm{Zn}-\mathrm{Cd}$ mixture. For TMI, separation coefficients for $\mathrm{Cu}$ (II) with regard to zinc and cadmium are 2.9 and 1.3, respectively. For DDMI separation coefficients for $\mathrm{Cu}$ (II) with regard to zinc and cadmium are 1.4 and 1.6, respectively. Sparingly soluble in water 1-decyl-2,4-dimethylimidazole is a more useful extractant. It can be used to separate $\mathrm{Zn}$ (II) from $\mathrm{Cd}$ (II) at a $\mathrm{pH}$ of $3-4.5$. 
Moreover, the investigation indicates that trialkylimidazole with all of the test metal cations tend to form 4-coordination complexes in addition to 6 -coordination ones in the solution. This is possible because, in the case of $\mathrm{Cu}, \mathrm{Cd}$ and $\mathrm{Zn}$ ions, a change of the coordination number takes place at various stages of complexation. Moreover, the configurational equilibrium tetrahedron $\leftrightarrow$ octahedron for $\mathrm{Zn}(\mathrm{II})$ is clearly shifted more to the right than for $\mathrm{Cd}(\mathrm{II})$. This leads to an increase in all total stability constants $\beta_{\mathrm{n}}$ and an increase in the values of their partition ratios $P_{n}$.

The new developments presented above were carried out within the 2007-2013 Innovative Economy Operational Programme, Sub-action 1.3.2., Support of the protection of industrial property generated by scientific entities as result of R\&D works within project no. UDA-POIG.01.03.02-04-077/12-01, financed by the European Regional Development Fund (ERDF) (85\% of co-financing) and from a designated subsidy (15\% of cofinancing).

\section{References}

1. C. Sgarlata, G. Arena, E. Longo, D. Zhang, Y. Yang, Bartsch R.A., J. Membr. Sci. 323, 444 (2008)

2. M.K. Jha, V. Kumar, J. Jeong, J. Lee, Hydrometallurgy 111-112, 1 (2012)

3. K.A. Schimmel, S. Ilias, S. Akella, Sep. Sci. Technol. 36, 805 (2001)

4. Agrawal, K.K. Sahu, J. Hazard. Mater. 171, 61 (2009)

5. G. Cote, Solv. Ext. Ion Exch. 18(4), 703 (2000)

6. E. Radzyminska-Lenarcik, Solv. Ext. Ion Exch. 25, 53 (2007)

7. E. Radzyminska-Lenarcik, Sep. Sci. Technol. 42, 2661 (2007)

8. F. Xie, D. Dreisinger, Solv. Ext. Ion Exch. 27, 459 (2009)

9. A. Kumari, M.K. Sinha, S.K. Sahu, B.D. Pandey, Hydrometallurgy 165, 159 (2016)

10. W. Apostoluk, Hydrometallurgy 21, 345 (1989)

11. K. Wejman-Gibas, M. Pilsniak-Rabiega, K. Ochromowicz, Physicochem. Probl. Miner. Process. 53, 202 (2017)

12. J.G.H. du Preez, Solv. Ext. Ion Exch. 18, 679 (2000)

13. J. Szymanowski, Hydrooximes and Copper Hydrometallurgy (CRC Press, Boca Raton, USA, 1993)

14. M. Ulewicz, K. Sadowska, J.F. Biernat, Desalination 214, 352 (2007)

15. M. Ulewicz, J. Szczygelska-Tao, J.F. Biernat, J. Membr. Sci. 344, 32 (2009)

16. S. Chun, S.V. Dzyuba, R.A. Bartsch, Anal. Chem. 73(15), 3737 (2001)

17. M.L.F. Gameiro, M.R.C. Ismael, M.T.A. Reis, J.M.R. Caravalaho, Sep. Purif. Technol. 63, 287 (2008)
18. G. Goetz, J. Arichi, Z. Lakkis, , J.P. Brunette, M. Hebrant, Solv. Ext. Ion Exch. 28, 793 (2010)

19. S.S. Sombhatla, A. Kumar, S. Mushruwala, K. Rokkam, A. Shukla, Hydrometall. 166, 94 (2016)

20. E. Radzyminska-Lenarcik, K. Witt. Sep. Sci. Technol.,DOI:10.1080/01496395.2017.1329838 (2017)

21. A. Borowiak-Resterna, H. Chlebowska, M. Giezek, Hydrometall. 103, 158 (2010)

22. M. Tomaszewska, A. Borowiak-Resterna, A. Olszanowski, Hydrometall. 85, 116 (2007)

23. E. Radzyminska-Lenarcik, Sep. Sci. Technol. 44, 954 (2009)

24. E. Radzyminska-Lenarcik, Solv. Ext. Ion Exch. 28, $636(2010)$

25. E. Radzyminska-Lenarcik, Chem. Pap. 65, 226 (2011)

26. B. Wassink, D. Dreisinger, J. Howard, Hydrometall. 57, 235 (2000)

27. M.E. Cuprey, US Patent 3,843,667. 22 October (1974)

28. J.G.H. du Preez, T.I.A. Gerber, W. Egde, V.L.V. Mtotywa, J.A.M. van Brecht, Solv. Ext. Ion Exch. 19, 143 (2001)

29. J.M. Schaekers, J.G.H. du Preez, US Patent US 2004/0208808 A1. 21 October (2004)

30. R.J. Sandberg, R.B. Martin, Chem Rev. 74, 471 (1974)

31. B. Lenarcik, B. Barszcz, Dalton Transactions, 24 (DOI:1039/DT9800000024) (1980)

32. B. Lenarcik, P. Ojczenasz, Sep. Sci. Technol. 39, 199 (2004)

33. B. Lenarcik, A. Kierzkowska, Solv. Ext. Ion Exch. 22, 449 (2004)

34. B. Lenarcik, A. Kierzkowska, Solv. Ext. Ion Exch. 24, 433 (2006)

35. E. Radzyminska-Lenarcik, K. Witt, Sep. Sci. Technol. 50, 676 (2015)

36. E. Radzyminska-Lenarcik, Sep. Sci. Technol. 43, 794 (2008)

37. B. Lenarcik, A. Kierzkowska, Sep. Sci. Technol. 39, 3485 (2004)

38. S. Nakatsuji, R. Nakajima, T. Hara, Bull. Che. Soc. Jpn. 42, 3598 (1969)

39. B. Lenarcik, K. Oblak, Roczniki Chemii 51, 2079 (1977)

40. B. Lenarcik, K. Kurdziel, R. Czopek, Solv. Ext. Ion Exch. 4, 165 (1986)

41. B. Lenarcik, K. Kurdziel, Polish J. Chem. 55, 737 (1981)

42. J. Rydberg, C. Musakis, G.R. Choppin, Principles and Practices of Solvent Extraction, vol.1 (M. Dekker, Inc., New York, 1992)

43. J. Gazo, I. B. Bersuker, J. Garaj, M. Kabesova, J. Kohout, H. Langfelderowa, M. Melnik, M. Serator, F. Valack, Coord. Chem. Rev. 19, 253 (1976) 